\title{
Liver transplantation in patients with hepatocellular carcinoma: factors implicated in tumor relapse
}

\author{
D. Martínez Ares, F. J. Suárez López, J. Souto Ruzo, A. Otero Ferreiro, M. Gómez Gutiérrez, \\ B. González Conde, C. Fernández Sellés, B. Gala López, F. Arnal Monreal and J. L. Vázquez Iglesias
}

Service of Digestive Diseases and Unit of Liver Transplantation. Complejo Hospitalario Universitario Juan Canalejo. A Coruña, Spain

\begin{abstract}
Introduction: liver segmental resection and liver transplantation are both treatments intended for healing liver cancer. An adequate selection of patients eligible for transplantation is crucial, since organs available for transplants are usually scarce. For this reason, awareness of the prognostic factors of relapse is of great importance. We present a comprehensive review of our series in order to better understand these prognostic factors.

Material and methods: we revised the cases of patients with hepatocellular carcinoma who underwent liver transplantation during the period 1994-2000, and present a detailed analysis of a series of variables which may be probably implicated in the appearance of relapse and which have an effect on survival.

Results: after a mean follow-up of 33 months, the mortality rate was $27.5 \%$ and relapse occurred in $18.75 \%$ of cases. No history of alcohol abuse, the number and size of the nodules, the presence of macro and microscopic vascular invasion, and pTNM stage T4 were all factors associated with a significantly increased risk of relapse $(p<0.05)$. These factors and positive HCV were associated to decreased survival. After a multivariate analysis, the size of the nodules and the presence of macroscopic vascular invasion were considered the only independent risk factors for tumor relapse and post-transplantation relapse and mortality, respectively.

Conclusions: macroscopic vascular invasion and tumor nodules larger than $5 \mathrm{~cm}$ are both independent risk factors of tumor relapse after transplantation. Nevertheless, only macroscopic vascular invasion seems to have a significant effect on survival
\end{abstract}

Key words: Hepatocellular carcinoma. Liver transplantation. Prognostic factors. Tumor relapse. Survival.

Recibido: 29-01-03.

Aceptado: 03-09-03.

Correspondencia: D. Martínez Ares. Servicio de Aparato Digestivo y Unidad de Trasplante Hepático. Complejo Hospitalario Universitario Juan Canalejo. C/ As Xubias de Arriba, 84. 15006 A Coruña. Tel.: 981128914 619983701.e-mail:martinezares@eresmas.com
Martínez Ares D, Suárez López FJ, Souto Ruzo J, Otero Ferreiro A, Gómez Gutiérrez M, González Conde B, Fernández Sellés C, Gala López B, Arnal Monreal F, Vázquez Iglesias JL. Liver transplantation in patients with hepatocellular carcinoma: factors implicated in tumor relapse. Rev Esp Enferm Dig 2004; 96: 22-31.

\section{INTRODUCTION}

Hepatocellular carcinoma is the commonest malignant tumor of the liver (1). It is clearly associated with cirrhosis of the liver, especially in geographical areas where viral hepatitis has a low incidence. In developing countries, where infection with hepatotrope viruses is endemic, up to $40 \%$ of all cases of liver carcinoma may appear in noncirrhotic livers. Chronic liver pathology due to alcohol abuse and liver pathology associated with chronic infection with hepatitis $\mathrm{C}$ virus $(\mathrm{HCV})$ and hepatitis $\mathrm{B}$ virus (HBV) are the usual substrate of hepatocellular carcinoma (2).

Several factors, such as increased survival of patients with liver cirrhosis, developments in diagnosis, followup programs, etc., have all contributed to a significant increase in the prevalence of this condition in recent years. Now, there are more efficient therapeutic modalities, and diagnosis is more often achieved in the early stages of the disease, when treatment targeted to cure the disease may be applied. Liver segmental resection and liver transplantation may help achieve a survival rate of $60-70 \%$ at five years in selected patients. In patients undergoing transplantation survival is similar to that expected in patients without liver carcinoma who undergo transplantation for end-stage liver disease (3).

According to the most recent trends (4), patients with a single nodule smaller than $5 \mathrm{~cm}$ who do not have portal hypertension and who have normal bilirubin are the ideal 
candidates for resection. In such cases, and although relapse is more frequent at five years, survival is similar to that observed when transplantation is the treatment of choice. In patients with several nodules (smaller than $3 \mathrm{~cm}$, and with a maximum of 3 nodules) and with a more advanced liver pathology, liver transplantation is considered the ideal approach, which will besides help cure the underlying hepatic disease (5).

The process of selecting patients eligible for healing treatment, and especially for liver transplantation, is now a commonly debated topic. This involves a discussion on the prognostic factors that may offer a better prognosis for mortality and tumor relapse after treatment. For this reason, we decided to revise the results in our series and assess those factors that, as regards tumor relapse and survival, may provide a better prognosis regarding the outcome of patients with hepatocellular carcinoma who undergo liver transplantation.

\section{MATERIAL AND METHODS}

\section{Patient selection}

We revised all the cases of patients who underwent liver transplantation at our center during the period 19442000. Of these, we selected the cases in which a hepatocellular carcinoma was detected in the explant, whether detection was the result of the intervention or an incidental finding.

\section{Variables studied}

We made a comprehensive study of the demographic variables and further analyzed over thirty variables, evaluating their potential prognostic influence. Of all these variables, we mention those considered of relevance or with clinical significance in previous studies. Thus, the level of serum alpha-fetoprotein, the number and size of nodules, the presence of an incidental tumor or tumor capsule, tumor growth pattern and tumor differentiation, gross and microscopic vascular invasion, tumor stage in the explant (pTNM), and etiology of the underlying liver condition (HCV or alcohol abuse) were all included in the statistical analysis.

\section{Statistical analysis}

The statistical analysis was performed using SPSS 11.5. Survival and tumor relapse rates were calculated by constructing Kaplan-Meier survival curves. Statistical significance was calculated by log-rank and Chi squared tests. Cox regression method was used for the multivariate analysis.

\section{RESULTS}

Three hundred and forty liver transplantations were performed in out center during this period. In 80 of these $(23.5 \%)$, the presence of hepatocellular carcinoma was the indication for transplantation in some cases, and an incidental finding in the explant in other. Of these 80 patients, 65 were males $(81.25 \%)$ and 15 were females (18.75\%). Patients' mean age was 52.6 years, similar to that of patients who underwent liver transplantation for other reasons. A follow-up period of 12 months was required as an inclusion criterion in the study. Mean follow-up was 33 months. A summary of these data can be seen in table I.

Twenty-two patients $(27.5 \%)$ died during follow-up. Kaplan-Meier curves (Fig. 1) were constructed, showing a survival probability of $63 \%$ at 60 months. Tumor relapse was the main cause of death $(54.5 \%)$, followed by viral relapse (18.2\%). Tumor relapse was seen in 15 cases, most of which were cases of systemic relapse $(66.7 \%)$. Regional relapse $(20 \%)$ and local relapse $(13.3 \%)$ were less frequent. Systemic relapse appeared in the form of bone (6 cases, 60\%), lung ( 3 cases, 30\%), and esophageal metastasis (one case, 10\%).

The hepatocellular carcinoma recurrence curve (Fig. 2) shows that the probability of relapse of the disease is $4 \%$ at one year, $15 \%$ at three years, and $18 \%$ at five years. Both curves show that most tumor relapses and deaths occurred within the first 24-36 months.

As regards tumor relapse after liver transplantation, a series of variables were analyzed (Table II). Of all the va-

Table I. Demographical variables and liver and renal function parameters in patients who underwent liver transplantation in our center

\begin{tabular}{|c|c|c|c|}
\hline & $\begin{array}{c}\text { Transplantations } \\
\text { with HCC }\end{array}$ & $\begin{array}{c}\text { Transplantations } \\
\text { without HCC }\end{array}$ & $p$ \\
\hline 80 & (77 with cirrhosis) & 260 & \\
\hline Age (years) & 52.6 & 51.4 & ns \\
\hline \multicolumn{4}{|l|}{ Sex } \\
\hline Males & $65(81.25 \%)$ & $195(75 \%)$ & ns \\
\hline Females & $15(18.75 \%)$ & $65(25 \%)$ & ns \\
\hline \multicolumn{4}{|l|}{ Child } \\
\hline A & $32(41 \%)$ & $3(0.8 \%)$ & \\
\hline$B$ & $28(36 \%)$ & $70(27 \%)$ & \\
\hline C & $17(22 \%)$ & $187(72 \%)$ & $p<0.05$ \\
\hline \multicolumn{4}{|l|}{ Etiology } \\
\hline Alcohol abuse & $33(41.2 \%)$ & $152(58.4 \%)$ & $p<0.05$ \\
\hline VCV & $40(50 \%)$ & $76(29.2 \%)$ & ns \\
\hline Other & $7(8.8 \%)$ & $32(12.4 \%)$ & ns \\
\hline Albumin (g/dl) & 3.3 & 2.6 & $p<0.05$ \\
\hline Bilirubin (mg/dl) & 1.8 & 3.1 & $p<0.05$ \\
\hline Creatinine $(\mathrm{mg} / \mathrm{dl})$ & 1.0 & 1.3 & ns \\
\hline
\end{tabular}




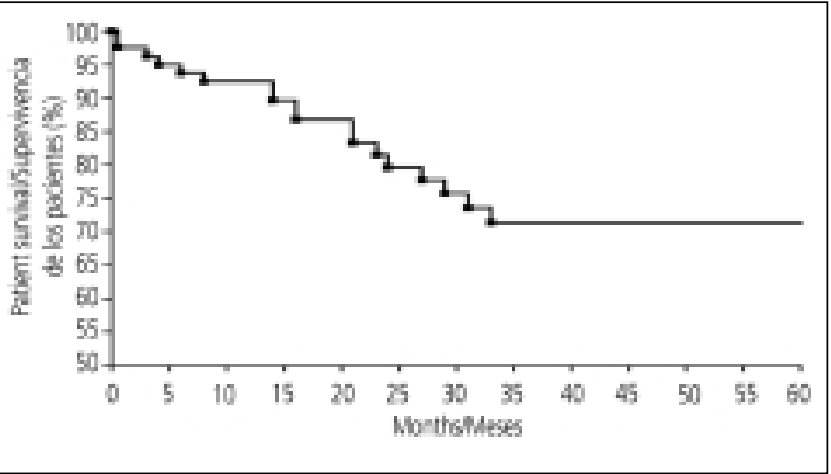

Fig. 1.- Probability of survival after liver transplantation in patients with hepatocellular carcinoma. Most deaths occur between the second and third years of follow-up. After the third year, survival remains stable Probabilidad de supervivencia tras trasplante hepático en pacientes con hepatocarcinoma. Se observa cómo la mayoría de los fallecimientos se producen entre el segundo y el tercer año de seguimiento. A partir de este momento, la supervivencia permanece estable.

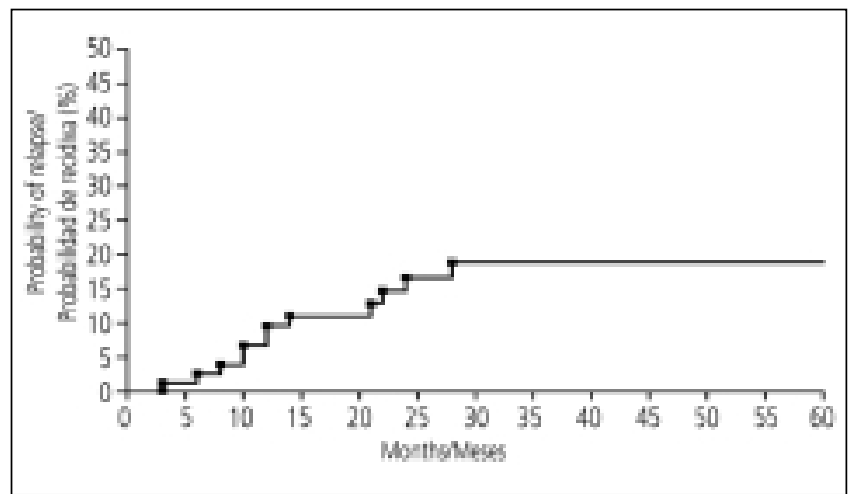

Fig. 2.- Cumulative tumor relapse probability after transplantation. The probability of recurrence for hepatocellular carcinomas is $4 \%$ at one year, $15 \%$ at three years, and $18 \%$ at five years

Probabilidad acumulada de recidiva tumoral tras el trasplante. La posibilidad de recurrencia de hepatocarcinoma es del $4 \%$ al año, del 15\% a los 3 años y del 18\% a los 5 años.

riables studied, only a non-alcohol abuse-related cause, number (multinodular) and size (larger than $5 \mathrm{~cm}$ ) of nodules, gross and microscopic vascular invasion, and pTNM stage T4 were associated with a significantly increased risk of relapse $(\mathrm{p}<0.05)$. Expansive growth pattern $(p=0.086)$ and lack of tumor capsule $(p=0.055)$ seemed to be associated with an increased risk of relapse, although these factors did not achieve statistical significance. Statistical significance might have been achieved if the series had included more cases, since we had only ten patients with infiltrative growth recorded. Data of CLIP (6) and BCLC7 stages, two staging methods which may help in the management of hepatocellular carcinoma and in the construction of decision trees (7) and algorithms to manage the disease, were included in the study. No statistically significant results were obtained in either case. In some groups this was due to the small number of patients included.
Table II. Influence of clinical-pathological variables on tumor relapse*

\begin{tabular}{|c|c|c|c|}
\hline Variables & $\begin{array}{l}\text { Number of } \\
\text { patients }\end{array}$ & $\begin{array}{c}\text { Tumor relapse } \\
\text { (\%) }\end{array}$ & $p$ \\
\hline \multicolumn{4}{|l|}{ Alpha fetoprotein } \\
\hline$<10$ & 23 & 25 & \\
\hline $10-100$ & 36 & 40 & 0.365 \\
\hline$>100$ & 21 & 42 & \\
\hline \multicolumn{4}{|l|}{$\mathrm{HCV}$} \\
\hline Positive & 40 & 25 & \\
\hline Negative & 40 & 12.5 & 0.126 \\
\hline \multicolumn{4}{|l|}{ History of alcohol abuse } \\
\hline Yes & 33 & 6.1 & \\
\hline No & 47 & 27.7 & 0.013 \\
\hline \multicolumn{4}{|l|}{ Number of nodules } \\
\hline Uninodular & 34 & 11.8 & \\
\hline Multinodular & 46 & 23.9 & 0.038 \\
\hline \multicolumn{4}{|l|}{ Size of nodule } \\
\hline $0-5 \mathrm{~cm}$ & 72 & 13.9 & \\
\hline$\geq 6 \mathrm{~cm}$ & 8 & 62.5 & 0.05 \\
\hline \multicolumn{4}{|l|}{ Tumor differentiation } \\
\hline Well differentiated & 29 & 20.7 & \\
\hline Moderately & 39 & 15.4 & \\
\hline Poorly & 12 & 25 & 0.719 \\
\hline \multicolumn{4}{|l|}{ Microscopic invasion } \\
\hline No & 58 & 10.3 & \\
\hline Yes & 22 & 40.9 & 0.004 \\
\hline \multicolumn{4}{|l|}{ Macroscopic invasion } \\
\hline No & 69 & 10.9 & \\
\hline Yes & 11 & 50 & 0.001 \\
\hline \multicolumn{4}{|l|}{ Incidental tumor } \\
\hline No & 66 & 19.7 & \\
\hline Yes & 14 & 14.3 & 0.485 \\
\hline \multicolumn{4}{|l|}{ Growth pattern } \\
\hline Expansive & 70 & 15.7 & \\
\hline Infiltrative & 10 & 40 & 0.086 \\
\hline \multicolumn{4}{|l|}{ Encapsulated tumor } \\
\hline Yes & 27 & 7.4 & \\
\hline No & 53 & 24.5 & 0.055 \\
\hline \multicolumn{4}{|l|}{ pTNM stage } \\
\hline T1 & 8 & 0 & \\
\hline T2 & 27 & 3.8 & \\
\hline T3 & 15 & 8.3 & \\
\hline T4 & 30 & 39.3 & 0.04 \\
\hline \multicolumn{4}{|l|}{ CLIP* } \\
\hline 0 & 10 & 30 & \\
\hline 1 & 17 & 6 & \\
\hline 2 & 32 & 9 & \\
\hline 3 & 3 & 0 & \\
\hline 4 & 1 & 0 & ns \\
\hline \multicolumn{4}{|l|}{$\mathrm{BCLC}^{*}$} \\
\hline A1 & 0 & & \\
\hline A2 & 5 & 20 & \\
\hline A3 & 26 & 3 & \\
\hline A4 & 27 & 11 & \\
\hline B & 5 & 60 & ns \\
\hline
\end{tabular}

the explant, were excluded.

After the multivariate analysis, the size of nodules and presence of macroscopic vascular invasion were considered the only independent risk factors of tumor relapse. Their relative risk is 9,$421 ; 95 \% \mathrm{CI}(1,080-82,206)$ for the former and 9,743 for the latter; $95 \%$ CI $(1,847-26,562)$. 
Regarding survival, an etiology different from a history of alcohol abuse, the number and size of tumor nodules, the presence of macroscopic vascular invasion, pTNM stage T4, and positive HCV were the factors associated with significantly decreased survival $(\mathrm{p}<0.05)$ (Table III). Although lacking statistical significance ( $\mathrm{p}=$ $0.08)$, microscopic vascular invasion was apparently associated with decreased survival rate. In the multivariate analysis, macroscopic vascular invasion was the only independent factor associated with increased mortality, with a relative risk of 23,351 and a CI $95 \%(3,503$, $155,673)$.

\section{DISCUSSION}

In recent years many attempts have been made to identify those factors that most accurately may predict risk of relapse for an hepatocellular carcinoma after liver transplantation $(8,9)$. As the number of candidates for this procedure increases, and organ availability decreases, an adequate selection of patients eligible for transplantation is even more important. Liver transplantation has been the usual treatment indicated for patients with only one tumor nodule of $5 \mathrm{~cm}$ or smaller, and patients with a maximum of three nodules (the biggest of which should not be larger than $3 \mathrm{~cm}$ ) of late. These restrictive criteria (known as Milan criteria) proved useful in identifying a group of patients with a low probability of recurrence (5). Notwithstanding, other authors have achieved similarly good results when patients with a size of up to $6.5 \mathrm{~cm}$ in the case of single tumors, and with a size of up to $4.5 \mathrm{~cm}$ when three tumor nodules were present, provided overall tumor diameter did not exceed $8 \mathrm{~cm}$ (these are the inclusion criteria known as San Francisco criteria) (10), were also included in their studies. In our country, Herrero et al. used similar criteria and achieved a free-of-disease survival of $70 \%$ at five years after transplantation (11). Thus, controversy arises when a subgroup of patients with a low probability of tumor recurrence are excluded due to very restrictive criteria (12).

There is a general agreement that standard TNM staging is not useful, since it does not allow a good prognosis for risk of relapse or survival in patients who have undergone liver transplantation. Moreover, a preoperative and postoperative comparison of pTNM staging shows that there is not much correlation in most cases $(11,13-15)$. In our series, patients with pT1, pT2 or pT3 stages did not show significant differences as for the risk of relapse and mean survival. Only pT4 proved to entail a significantly higher risk of mortality and of tumor relapse. However, given the level of knowledge on this condition nowadays, patients with a different prognosis are included in this stage: a patient with a single nodule of $4 \mathrm{~cm}$ in size and with macroscopic vascular invasion will have a poorer prognosis when compared
Table III. Influence of clinical-pathologic variables on survival*

\begin{tabular}{|c|c|c|c|}
\hline Variables & $\begin{array}{l}\text { Number of } \\
\text { patients }\end{array}$ & $\begin{array}{c}\text { Tumor relapse } \\
\text { (\%) }\end{array}$ & $p$ \\
\hline \multicolumn{4}{|l|}{ Alpha fetoprotein } \\
\hline$<10$ & 23 & 20 & \\
\hline $10-100$ & 36 & 37 & 0.1785 \\
\hline$>100$ & 21 & 38 & \\
\hline \multicolumn{4}{|l|}{$\mathrm{HCV}$} \\
\hline Positive & 40 & 17.5 & \\
\hline Negative & 40 & 37.5 & 0.0427 \\
\hline \multicolumn{4}{|l|}{ History of alcohol abuse } \\
\hline Yes & 33 & 12 & \\
\hline No & 47 & 37 & 0.0106 \\
\hline \multicolumn{4}{|l|}{ Number of nodules } \\
\hline Uninodular & 34 & 14.7 & \\
\hline Multinodular & 46 & 36.9 & 0.0472 \\
\hline \multicolumn{4}{|l|}{ Size nodules } \\
\hline $0-5 \mathrm{~cm}$ & 72 & 23.6 & \\
\hline$\geq 6 \mathrm{~cm}$ & 8 & 62.5 & 0.0356 \\
\hline \multicolumn{4}{|l|}{ Tumor differentiation } \\
\hline Well differentiated & 29 & 31 & \\
\hline Moderately & 39 & 25 & \\
\hline Poorly & 12 & 25 & 0.9943 \\
\hline \multicolumn{4}{|l|}{ Microscopic invasion } \\
\hline No & 58 & 22.4 & \\
\hline Yes & 22 & 40.9 & 0.0807 \\
\hline \multicolumn{4}{|l|}{ Microscopic invasion } \\
\hline Yes & 69 & 17.1 & \\
\hline No & 11 & 68.75 & 0.0001 \\
\hline \multicolumn{4}{|l|}{ Incidental tumor } \\
\hline No & 66 & 20.7 & \\
\hline Yes & 14 & 14.3 & 0.485 \\
\hline \multicolumn{4}{|l|}{ Growth pattern } \\
\hline Expansive & 70 & 28.2 & \\
\hline Infiltrative & 10 & 45 & 0.106 \\
\hline \multicolumn{4}{|l|}{ Encapsulated tumor } \\
\hline Yes & 27 & 9.4 & \\
\hline No & 53 & 24.5 & 0.095 \\
\hline \multicolumn{4}{|l|}{ pTNM stage } \\
\hline $\mathrm{T} 1$ & 8 & 0 & \\
\hline $\mathrm{T} 2$ & 27 & 4.5 & \\
\hline T3 & 15 & 9.6 & \\
\hline T4 & 30 & 48.3 & 0.032 \\
\hline \multicolumn{4}{|l|}{ CLIP* } \\
\hline 0 & 10 & 40 & \\
\hline 1 & 17 & 17 & \\
\hline 2 & 32 & 25 & \\
\hline 3 & 3 & 66 & \\
\hline 4 & 1 & 0 & ns \\
\hline \multicolumn{4}{|l|}{$B C L C$ * } \\
\hline A1 & 0 & & \\
\hline A2 & 5 & 20 & \\
\hline A3 & 26 & 19 & \\
\hline A4 & 27 & 30 & \\
\hline B & 5 & 80 & ns \\
\hline
\end{tabular}

*17 patients, three of them without cirrhosis and 14 with an incidental tumor in the explant, were excluded.

to a patient with two nodules of $2 \mathrm{~cm}$ each, one in the LHL, the other in the RHL, and both of them showing no vascular invasion. 
In most studies, macroscopic vascular invasion is considered the most important prognostic factor for relapse and survival $(16,17)$. The results in our study correlate with the results of previously published studies. However, the fact that this type of invasion is usually identified by the pathologist after an examination of the explant, where he can see a macroscopically visible vessel (usually larger than $2 \mathrm{~mm}$ ) infiltrated by the tumor, implies a certain limitation. Thus, the objective should be the preoperative identification of this type of infiltration.

Unlike other authors, we think there is no relation between level of alpha-fetoprotein and risk of tumor recurrence $(10,18)$. We found no significant differences regarding risk of relapse and influence on survival. However, authors who consider that this has prognostic value reached statistical significance only when alpha-fetoprotein levels were over 300 and even up to $1,000 \mathrm{ng} / \mathrm{mL}$. In our study, however, $100 \mathrm{ng} / \mathrm{mL}$ was considered the acceptable limit, and only 8 patients had AFP > $300 \mathrm{ng} / \mathrm{mL}$.

In our study, the presence of a tumor nodule larger than $5 \mathrm{~cm}$ was accompanied by a significantly increased risk of relapse, although this fact does not have a significant effect on survival. This has also been noticed by other authors $(19,20)$, who also found significant differences in survival and risk of relapse in relation to the number of nodules and their unilobular o bilobular distribution. In our case, these factors achieved statistical significance in the univariate analysis, but were not considered independent risk factors after the multivariate analysis.

A significantly increased mortality rate in the group of $\mathrm{HCV}$-positive patients was a finding not seen in other series. After a detailed study of these cases (Table IV), we saw that most patients had died as a consequence of tumor relapse, which also happened in the group of patients with transplantation for hepatocellular carcinoma. Although there were no statistically significant differences, we found out that diagnosis was reached in more advanced stages of the disease in the case of HCV-positive patients, although follow-up had been the same in all groups (and all cases correlated with the current consensus) $(21,22)$. At least half of HCV-positive patients are diagnosed when the disease is in stage pT4, while in $48.7 \%$ of HCV-negative patients a diagnosis is reached in stage $\mathrm{pT} 1$ or $\mathrm{pT} 2(\mathrm{p}=0.087)$.

From our results we conclude that the degree of tumor differentiation, and the fact that hepatocellular carcinoma is an incidental finding in the explant (and not an indication for transplantation), are variables that lack prognostic value. The low number of patients with poorly differentiated tumors $(15 \%)$ may be a reason that statistical significance was not reached. Nevertheless, statistical significance has been achieved in wider series, including approximately 800 cases of transplantation for hepatocellular carcinoma registered in the International Tumor Registry (23-26). On the other hand, other authors (27)
Table IV. Liver carcinoma in HCV-positive patients

\begin{tabular}{lll}
\hline & HCV positive & HCV negative \\
\hline Number of cases & 40 & 40 \\
Mortality (\%) & 37.5 & 17.5 \\
Tumor relapse (\%) & 25 & 12.5 \\
$\begin{array}{l}\text { Cause of death (\%) } \\
\quad \text { Tumor relapse }\end{array}$ & $8(53.3 \%)$ & $4(57.1 \%)$ \\
$\quad$ Viral relapse & $3(20 \%)$ & $1(14.3 \%)$ \\
$\quad$ Other & $2(16.7 \%)$ & $4(28.1 \%)$ \\
Tumor stage (\%) & & \\
$\quad$ pT1 & 7.5 & 12.8 \\
pT2 & 30 & 35.9 \\
pT3 & 12.5 & 17.9 \\
pT4 & 50 & $33.3(\mathrm{p}=0.087)$ \\
\hline
\end{tabular}

have mentioned that these incidental tumors are of little value, since they found up to $30 \%$ cases of vascular invasion in them. An expansive growth pattern and the lack of tumor capsule are factors that, despite not having statistical significance, are usually accompanied by an increased risk of tumor relapse that may be related to the fact that vascular invasion and a more remarkable tumor growth are more probable in this situation.

To conclude, our opinion is that standard TNM staging is a poorly useful and anachronical technique. We also believe that gross and microscopic vascular invasion, and nodules larger than $5 \mathrm{~cm}$ allow better prediction for increased risk of relapse, although only macroscopic vascular invasion significantly reduces survival. Finally, patients with chronic liver pathology for $\mathrm{HCV}$ and hepatocellular carcinoma who have undergone transplantation have a decreased long-term survival, probably due to the fact that tumors are in a more advanced stage at diagnosis in their case.

\section{REFERENCES}

1. Bruix J, Llovet JM, Beaugrand M, Lencioni R, Burroughs AK, Christensen E, et al. Clinical management of hepatocellular carcinoma. Conclusions of the Barcelona-2000 EASL Conference. Journal of Hepato$\operatorname{logy} 2001 ; 35 \mathrm{k}(3)$ : 421-30.

2. Befeler AS, Di Bisceglie AM. Hepatocellular carcinoma: diagnosis and treatment. Gastroenterology 2002; 122 (6): 1609-19.

3. Wong LL. Current status of liver transplantation for hepatocellular cancer. Am J Surg 2002; 183 (3): 309-16.

4. Bruix J, Llovet JM. Prognostic prediction and treatment strategy in hepatocellular carcinoma. Hepatology 2002; 35: 519-24.

5. Mazzaferro V, Regalia E, Doci R, Andreola S, Pulvirenti A, Bozzetti F, et al. Liver transplantation for the treatment of small hepatocellular carcinoma in patients with cirrhosis. N Engl J Med 1996; 334: 639-99.

6. The Cancer of the Liver Italian Program (CLIP) Investigators. Prospective validation of the CLIP score: a new prognostic system for patients with cirrhosis and hepatocellular carcinoma. Hepatology 2000; 31 (4): 840-5.

7. Llovet JM, Brú C, Bruix J. Prognosis of hepatocellular carcinoma: the BCLC staging classification. Semin Liv Dis 1999; 19 (3): 329-38.

8. Iwatsuki S, Dvorchik I, Marsh JW, Madariaga JR, Carr B, Fung JJ, et al. Liver transplantation for hepatocellular carcinoma: a proposal of a prognostic scoring system. J Am Coll Surgery 2000; 191 (5): 389-94.

9. Marsh JW, Dvorchik I, Subotin M, Balan V, Rakela J, Popechitelev $\mathrm{EP}$, et al. The prediction risk of recurrence and time to recurrence of 
hepatocellular carcinoma after orthotopic liver transplantation: a pilot study. Hepatology 1997; 26: 444-50.

10. Yao FY, Ferrell L, Bass NM, Watson JJ, Bachetti P, Venook A, et al. Liver transplantation for hepatocellular carcinoma: expansion of the tumor size limits does not adversely impact survival. Hepatology 2001; 33: 1394-403.

11. Herrero JI, Sangro B, Quiroga J, Pardo F, Herraiz M, Cienfuegos JA, et al. Influence of tumor characteristics on the outcome of liver transplantation among patients with liver cirrhosis and hepatocellular carcinoma. Liver Transpl Surg 2001; 7 (7): 631-6.

12. Yao FY, Ferrell L, Bass NM, Watson JJ, Bachetti P, Ascher NL, et al. Liver transplantation for hepatocellular carcinoma: comparison of the proposed UCSF criteria with the Milan criteria and the Pittsburgh modified TNM criteria. Liver Transpl Surg 2002; 8 (9): 765 74.

13. Llovet JM, Bruix J, Fuster J, Castells A, García-Valdecasas JC, Grande L, et al. Liver transplantation for small hepatocellular carcinoma: the tumor-node-metastasis classification doe not have prognostic power. Hepatology 1998; 27: 1572-83.

14. Marsh JW, Dvorchik I, Bonham CA, Iwatsuki S. Is the pathologic TNM staging system for patients with hepatocellular carcinoma predictive of outcome? Cancer 2000; 88 (3): 538-43.

15. Ringe B, Pichlmyr R, Wittekind D, Tush G. Surgical treatment of hepatocellular carcinoma: experience with liver resection and transplantation in 198 patients. World J Surg 1991; 15: 270-85.

16. Molmenti EP, Marsh JW, Dvorchik I, Oliver JH 3rd, Madariaga J, Iwatsuki S. Hepatobiliary malignancies. Primary hepatic malignant neoplasms. Surg Clin North Am 1999; 79: 43-57.

17. Kirimlioglu H, Dvorchik I, Ruppert K, Finkelstein S, Marsh JW, Iwatsuki $S$, et al. Hepatocellular carcinomas in native livers from patients treated with orthotopic liver transplantation: biologic and thera- peutic implications. Hepatology 2001: 34: 502-10.

18. Figueras J, Ibáñez L, Ramos E, Jaurrieta E, Ortiz-de Urbina J, Pardo $\mathrm{F}$, et al. Selection criteria for liver transplantation in early-stage hepatocellular carcinoma with cirrhosis: results of a multicenter study. Liver Transplantation 2001; 7 (10): 877-83.

19. Frilling A, Malago M, Broelsch CE. Current status of liver transplantation for treatment of hepatocellular carcinoma. Dig Dis 2001; 19 (4): 333-7.

20. Suárez Y, Franca AC, Llovet JM, Fuster J, Bruix J. The current status of liver transplantation for primary hepatic malignancy. Clin Liver Dis 2000; 4 (3): 591-605.

21. Dusheiko GM, Hobbs KE, Dick R, Burroughs AK. Treatment of small hepatocellular carcinomas. Lancet 1992; 340 (8814): 285-8.

22. Ribeiro A, Nagorney DM, Gores GJ. Localized hepatocellular carcinoma: therapeutic options. Curr Gastroenterol Rep 2000; 2 (1): 72-81.

23. Klintmalm GB. Liver transplantation for hepatocellular carcinoma: a registry of the impact of tumor characteristics on outcome. Ann Surg 1998; 228: 479-88.

24. Tamura S, Kato T, Berho M, Misiakos EP, O’Brien C, Reddy Kr, et al. Impact of histologic grade of hepatocellular carcinoma on the outcome of liver transplantation. Arch Surg 2001; 136: 25-30.

25. O’Grady JG, Polson RJ, Rolles K, Williams R. Liver transplantation for malignant disease: results in 93 consecutive patients. Ann Surg 1988; 207: 373-9.

26. Jonas S, Bechstein WO, Steinmuller T, Herrman M, Radke C, Berg T, et al. Vascular invasion and histologic grading determine outcome after liver transplantation for hepatocellular carcinoma in cirrhosis. Hepatology 2001; 33: 1080-6.

27. Ackhar JP, Araya V, Baron RL, Marsh JW, Dvorchik I, Rakela J. Undetected hepatocellular carcinoma: clinical features and outcome after liver transplantation. Liver Transpl Surg 1998; 4 (6): 477-82.

\title{
Trasplante hepático en pacientes con hepatocarcinoma: factores implicados en la recidiva tumoral
}

\author{
D. Martínez Ares, F. J. Suárez López, J. Souto Ruzo, A. Otero Ferreiro, M. Gómez Gutiérrez, B. \\ González Conde, C. Fernández Sellés, B. Gala López, F. Arnal Monreal y J. L. Vázquez Iglesias \\ Servicio de Aparato Digestivo y Unidad de Trasplante Hepático. Complejo Hospitalario Universitario Juan Canalejo. \\ A Coruña
}

\section{RESUMEN}

Introducción: tanto la resección hepática segmentaria como el trasplante hepático son tratamientos con intención curativa para el hepatocarcinoma. La adecuada selección de los pacientes para el trasplante es de vital importancia dada la escasa disponibilidad de órganos. Por ello resulta fundamental el conocer los factores predictivos de recidiva tumoral, motivo por el que hacemos una exhaustiva revisión de nuestra serie.

Material y métodos: revisamos los pacientes con hepatocarcinoma trasplantados en el periodo 1994-2000, y analizamos detalladamente una serie de variables con probable implicación en la recidiva tumoral y repercusión sobre la supervivencia.

Resultados: tras un seguimiento medio de 33 meses, la mortalidad fue del $27,5 \%$ y la tasa de recidiva del $18,75 \%$. La ausencia de alcoholismo, el número y el tamaño de nódulos, la invasión vascular macro y microscópica, y un estadio T4 en el clásico pTNM, se asociaban con un riesgo significativamente mayor de recidiva $(p<0,05)$. Estos mismos factores y la positividad para el HCV se asociaron con una menor supervivencia. Tras el análisis multivariante, sólo el tamaño de los nódulos para la recidiva tumoral, y la invasión vascular macroscópica para la recidiva y la mortalidad postrasplante, pudieron ser considerados factores de riesgo independientes.

Conclusiones: la invasión vascular macroscópica y un tamaño superior a $5 \mathrm{~cm}$ de los nódulos tumorales son factores de riesgo independientes para la recidiva tumoral después del trasplante, aunque sólo la invasión vascular macroscópica parece afectar de forma significativa a la supervivencia.

Palabras clave: Hepatocarcinoma. Trasplante hepático. Factores pronósticos. Recidiva tumoral. Supervivencia. 


\section{INTRODUCCIÓN}

El hepatocarcinoma es el tumor maligno más frecuente en el hígado (1). Está claramente ligado a la presencia de cirrosis hepática, especialmente en las áreas de baja incidencia de hepatitis víricas. En los países subdesarrollados, donde la infección por virus hepatotropos es endémica, hasta un $40 \%$ de los hepatocarcinomas pueden presentarse sobre hígados no cirróticos. En general, la hepatopatía crónica etílica y la asociada a la infección crónica por el virus de la hepatitis $\mathrm{C}$ (VHC) y y virus de la hepatitis B (VHB) son el sustrato sobre el que habitualmente asienta el carcinoma hepatocelular (2).

En los últimos años se ha registrado un importante incremento en su prevalencia motivado por múltiples factores, como la mayor supervivencia de los pacientes con cirrosis hepática, la mejoría de los medios diagnósticos, los programas de seguimiento, etc. Actualmente, además de contar con modalidades terapéuticas más eficaces, el diagnóstico se realiza con mayor frecuencia en estadios iniciales, en los que tratamientos con intención curativa son factibles. La resección hepática segmentaria y el trasplante hepático logran, en pacientes bien seleccionados, una supervivencia en torno al 60-70\% a los 5 años, hasta el punto de que en los pacientes trasplantados la supervivencia no dista sustancialmente de la esperada en los pacientes trasplantados por una hepatopatía terminal sin hepatocarcinoma (3).

Según las últimas tendencias (4), los pacientes con un nódulo único menor de $5 \mathrm{~cm}$, sin hipertensión portal y con bilirrubina normal, son los candidatos ideales para la cirugía de resección, con igual supervivencia que el trasplante, aunque con mayor tasa de recidivas a los cinco años. En los pacientes con varios nódulos (menos de 3 , y con un máximo de $3 \mathrm{~cm}$ ) y con hepatopatía más avanzada, la solución ideal es el trasplante hepático, que también resolverá la enfermedad hepática de base (5).

Un tema sometido a continuo debate en el momento actual es el de la selección adecuada de los pacientes para un tratamiento curativo, especialmente para el trasplante hepático. Esto equivale a discutir sobre los factores pronósticos con mayor poder predictivo de la recidiva tumoral y la mortalidad después del tratamiento. Por este motivo hemos decidido revisar los resultados de nuestra serie, analizando los factores que nos permitan predecir con mayor fiabilidad el devenir de los pacientes con hepatocarcinoma trasplantados, en cuanto a la recidiva tumoral y la supervivencia.

\section{MATERIAL Y MÉTODOS}

\section{Selección de pacientes}

Hemos revisado todos los trasplantes hepáticos realizados en nuestro centro durante el periodo de 1994-2000. De ellos hemos seleccionado los pacientes en los que, en el explante, se detectó un hepatocarcinoma tanto si el mismo era la indicación de la intervención como si se trataba de un hallazgo incidental.

\begin{tabular}{|c|c|c|c|}
\hline & $\begin{array}{c}\text { Trasplantados } \\
\text { con HCC }\end{array}$ & $\begin{array}{c}\text { Trasplantados } \\
\text { sin HCC }\end{array}$ & $p$ \\
\hline 80 & 0 (77 con cirrosis) & 260 & \\
\hline Edad (años) & 52,6 & 51,4 & ns \\
\hline \multicolumn{4}{|l|}{ Sexo } \\
\hline Varones & $65(81,25 \%)$ & $195(75 \%)$ & ns \\
\hline Mujeres & $15(18,75 \%)$ & $65(25 \%)$ & ns \\
\hline \multicolumn{4}{|l|}{ Child } \\
\hline A & $32(41 \%)$ & $3(0,8 \%)$ & \\
\hline B & $28(36 \%)$ & $70(27 \%)$ & \\
\hline C & $17(22 \%)$ & $187(72 \%)$ & $p<0,05$ \\
\hline \multicolumn{4}{|l|}{ Etiología } \\
\hline Alcoholismo & $33(41,2 \%)$ & 152 (58,4\%) & $p<0,05$ \\
\hline VHC & $40(50 \%)$ & $76(29,2 \%)$ & ns \\
\hline Otras & $7(8,8 \%)$ & $32(12,4 \%)$ & ns \\
\hline Albúmina (g/dl) & 3,3 & 2,6 & $p<0,05$ \\
\hline Bilirrubina (mg/dl) & 1,8 & 3,1 & $p<0,05$ \\
\hline Creatinina (mg/dl) & 1,0 & 1,3 & ns \\
\hline
\end{tabular}

\section{Variables estudiadas}

Realizamos un exhaustivo estudio de las variables demográficas, y posteriormente analizamos más de treinta variables teniendo en cuenta su posible implicación pronóstica. De todas ellas nos referiremos a aquellas que habían sido consideradas relevantes en estudios publicados con anterioridad o, consideradas con trascendencia clínica. Así, fueron incluidos en el estudio estadístico el nivel de alfafetoproteína sérica, número y tamaño de los nódulos, presencia de tumor incidental, existencia de cápsula tumoral, patrón de crecimiento y grado de diferenciación tumoral, la invasión vascular macroscópica y microscópica, el estadio tumoral en el explante (pTNM) y la etiología de la hepatopatía de base (HCV o alcoholismo principalmente).

\section{Análisis estadístico}

El análisis estadístico se realizó por medio del paquete estadístico SPSS 11.5. La probabilidad de supervivencia y de recidiva tumoral se calculó en base a las curvas de supervivencia de Kaplan-Meier. La significación estadística se calculó aplicando el test de log-rank y la prueba Chi cuadrado. El análisis multivariante fue realizado con el método de la regresión logística de Cox.

\section{RESULTADOS}

Durante este periodo de tiempo se han llevado a cabo en nuestro centro un total de 340 trasplantes hepáticos. 
En 80 de ellos $(23,5 \%)$ el hepatocarcinoma fue la indicación del trasplante o bien fue un hallazgo incidental en el explante. La distribución por sexos era claramente desigual: 65 varones $(81,25 \%)$ y 15 mujeres $(18,75 \%)$. La edad media era de 52,6 años, lo que no distaba significativamente de la edad media de los pacientes sometidos a TOH por otros motivos. El seguimiento mínimo exigido para incluir a los pacientes en el presente estudio se estableció en 12 meses, y el seguimiento medio fue de 33 meses. Todos estos datos se resumen en la tabla I.

A lo largo del seguimiento se registraron un total de 22 fallecimientos $(27,5 \%)$. Se construyó la curva de supervivencia de Kaplan-Meier (Fig. 1), obteniéndose una probabilidad de supervivencia a los 60 meses del 63\%. La principal causa de muerte fue la recidiva tumoral $(54,5 \%)$, seguida de la recidiva viral $(18,2 \%)$. La recidiva tumoral se objetivó en 15 casos, que fue mayoritariamente sistémica $(66,7 \%)$; la recidiva regional $(20 \%)$ y la recidiva local $(13,3 \%)$ fueron mucho menos frecuentes. La recidiva sistémica consistió en metástasis óseas en 6 casos $(60 \%)$, metástasis pulmonares en $3(30 \%)$ y esofágica en 1 caso (10\%).

De la curva de probabilidad de recurrencia del hepatocarcinoma (Fig. 2) se deduce que la probabilidad de recidiva es del $4 \%$ al año, del $15 \%$ a los 3 años y del $18 \%$ a los 5 años. Tras el examen de las dos curvas se puede observar cómo la mayoría de las recidivas tumorales, así como de los fallecimientos, ocurren en los primeros 2436 meses.

En relación con la recidiva tumoral después del trasplante hepático, se evaluaron una serie de variables (Tabla II). De todas ellas, sólo la etiología diferente al alcoholismo, el número de nódulos (tumor multinodular), el tamaño de los mismos (mayor de $5 \mathrm{~cm}$ ), la invasión vascular macro y microscópica, y un estadio T4 en el clásico pTNM, se asociaban con un riesgo significativamente mayor de recidiva $(\mathrm{p}<0,05)$. Un patrón de crecimiento expansivo $(\mathrm{p}=0,086)$ y la ausencia de cápsula tumoral $(\mathrm{p}=0,055)$, aunque no alcanzaron significación estadística, parecen asociarse con un mayor riesgo de recidiva. La significación estadística se alcanzaría con toda seguridad si la serie fuese un poco más amplia, ya que tan sólo teníamos recogidos diez casos con crecimiento infiltrativo. Fueron incluidos en el estudio los datos correspondientes al estadio CLIP (6) y BCLC (7), dos sistemas de estadificación que pueden facilitar el manejo del carcinoma hepatocelular, incluso a través de la elaboración de algoritmos o árboles de decisión (7). En ninguno de los dos casos, por el reducido número de pacientes en alguno de los grupos, se han obtenido resultados estadísticamente significativos.

Tras realizar el análisis multivariante se comprueba que el tamaño de los nódulos y la invasión vascular macroscópica son los únicos que podemos considerar factores de riesgo independientes para recidiva tumoral. Sus riesgos relativos son 9.421 con un IC al $95 \%$ (1.080,
Tabla II. Influencia de variables clínico-patológicas en la recidiva tumoral*

\begin{tabular}{|c|c|c|c|}
\hline Variable & $\begin{array}{l}\text { Número de } \\
\text { pacientes }\end{array}$ & $\begin{array}{l}\text { Recidiva tumoral } \\
\text { (\%) }\end{array}$ & $p$ \\
\hline \multicolumn{4}{|l|}{ Alfafetoproteína } \\
\hline$<10$ & 23 & 25 & \\
\hline $10-100$ & 36 & 40 & 0,365 \\
\hline$>100$ & 21 & 42 & \\
\hline \multicolumn{4}{|l|}{$\mathrm{HCV}$} \\
\hline Positivo & 40 & 25 & \\
\hline Negativo & 40 & 12,5 & 0,126 \\
\hline \multicolumn{4}{|l|}{ Alcoholismo } \\
\hline Presente & 33 & 6,1 & \\
\hline Ausente & 47 & 27,7 & 0,013 \\
\hline \multicolumn{4}{|l|}{ Número nódulos } \\
\hline Uninodular & 34 & 11,8 & \\
\hline Multinodular & 46 & 23,9 & 0,038 \\
\hline \multicolumn{4}{|l|}{ Tamaño nódulos } \\
\hline $0-5 \mathrm{~cm}$ & 72 & 13,9 & \\
\hline$\geq 6 \mathrm{~cm}$ & 8 & 62,5 & 0,05 \\
\hline \multicolumn{4}{|l|}{ Diferenciación tum. } \\
\hline Bien diferenc. & 29 & 20,7 & \\
\hline Moderadamente & 39 & 15,4 & \\
\hline Pobremente & 12 & 25 & 0,719 \\
\hline \multicolumn{4}{|l|}{ Inv. microscópica } \\
\hline Ausente & 58 & 10,3 & \\
\hline Presente & 22 & 40,9 & 0,004 \\
\hline \multicolumn{4}{|l|}{ I. macroscópica } \\
\hline Ausente & 69 & 10,9 & \\
\hline Presente & 11 & 50 & 0,001 \\
\hline \multicolumn{4}{|l|}{ Tumor incidental } \\
\hline Ausente & 66 & 19,7 & \\
\hline Presente & 14 & 14,3 & 0,485 \\
\hline \multicolumn{4}{|l|}{ Patrón crecimiento } \\
\hline Expansivo & 70 & 15,7 & \\
\hline Infiltrativo & 10 & 40 & 0,086 \\
\hline \multicolumn{4}{|l|}{ Tumor encapsulado } \\
\hline Sí & 27 & 7,4 & \\
\hline No & 53 & 24,5 & 0,055 \\
\hline \multicolumn{4}{|l|}{ Estadiaje pTNM } \\
\hline T1 & 8 & 0 & \\
\hline $\mathrm{T} 2$ & 27 & 3,8 & \\
\hline T3 & 15 & 8,3 & \\
\hline T4 & 30 & 39,3 & 0,04 \\
\hline \multicolumn{4}{|l|}{ CLIP* } \\
\hline 0 & 10 & 30 & \\
\hline 1 & 17 & 6 & \\
\hline 2 & 32 & 9 & \\
\hline 3 & 3 & 0 & \\
\hline 4 & 1 & 0 & ns \\
\hline \multicolumn{4}{|l|}{$B C L C$ * } \\
\hline A1 & 0 & & \\
\hline A2 & 5 & 20 & \\
\hline A3 & 26 & 3 & \\
\hline A4 & 27 & 11 & \\
\hline B & 5 & 60 & ns \\
\hline
\end{tabular}

*Han sido excluidos 17 pacientes, 3 sin cirrosis y 14 con tumores incidentales en el explante.

82.206) para el primero y 9.743 para el segundo, siendo su IC al $95 \%$ (1.847, 26.562).

En lo que a la supervivencia se refiere, los factores que se asociaron a una supervivencia significativamente me- 
Tabla III. Influencia de variables clínico-patológicas en la supervivencia*

\begin{tabular}{|c|c|c|c|}
\hline Variable & $\begin{array}{l}\text { Número de } \\
\text { pacientes }\end{array}$ & $\begin{array}{c}\text { Recidiva tumoral } \\
\text { (\%) }\end{array}$ & $p$ \\
\hline \multicolumn{4}{|l|}{ Alfafetoproteína } \\
\hline$<10$ & 23 & 20 & \\
\hline $10-100$ & 36 & 37 & 0,1785 \\
\hline$>100$ & 21 & 38 & \\
\hline \multicolumn{4}{|l|}{$\mathrm{HCV}$} \\
\hline Positivo & 40 & 17,5 & \\
\hline Negativo & 40 & 37,5 & 0,0427 \\
\hline \multicolumn{4}{|l|}{ Alcoholismo } \\
\hline Presente & 33 & 12 & \\
\hline Ausente & 47 & 37 & 0,0106 \\
\hline \multicolumn{4}{|l|}{ Número nódulos } \\
\hline Uninodular & 34 & 14,7 & \\
\hline Multinodular & 46 & 36,9 & 0,0472 \\
\hline \multicolumn{4}{|l|}{ Tamaño nódulos } \\
\hline $0-5 \mathrm{~cm}$ & 72 & 23,6 & \\
\hline$\geq 6 \mathrm{~cm}$ & 8 & 62,5 & 0,0356 \\
\hline \multicolumn{4}{|l|}{ Diferenciación tum. } \\
\hline Bien diferenc. & 29 & 31 & \\
\hline Moderadamente & 39 & 25 & \\
\hline Pobremente & 12 & 25 & 0,9943 \\
\hline \multicolumn{4}{|l|}{ Inv.microscópica } \\
\hline Ausente & 58 & 22,4 & \\
\hline Presente & 22 & 40,9 & 0,0807 \\
\hline \multicolumn{4}{|l|}{ I. macroscópica } \\
\hline Ausente & 69 & 17,1 & \\
\hline Presente & 11 & 68,75 & 0,0001 \\
\hline \multicolumn{4}{|l|}{ Tumor incidental } \\
\hline Ausente & 66 & 20,7 & \\
\hline Presente & 14 & 14,3 & 0,485 \\
\hline \multicolumn{4}{|l|}{ Patrón crecimiento } \\
\hline Expansivo & 70 & 28,2 & \\
\hline Infiltrativo & 10 & 45 & 0,106 \\
\hline \multicolumn{4}{|l|}{ Tumor encapsulado } \\
\hline Sí & 27 & 9,4 & \\
\hline No & 53 & 24,5 & 0,095 \\
\hline \multicolumn{4}{|l|}{ Estadiaje pTNM } \\
\hline $\mathrm{T} 1$ & 8 & 0 & \\
\hline $\mathrm{T} 2$ & 27 & 4,5 & \\
\hline T3 & 15 & 9,6 & \\
\hline T4 & 30 & 48,3 & 0,032 \\
\hline \multicolumn{4}{|l|}{ CLIP* } \\
\hline 0 & 10 & 40 & \\
\hline 1 & 17 & 17 & \\
\hline 2 & 32 & 25 & \\
\hline 3 & 3 & 66 & \\
\hline 4 & 1 & 0 & ns \\
\hline \multicolumn{4}{|l|}{$\mathrm{BCLC}^{*}$} \\
\hline A1 & 0 & & \\
\hline$A 2$ & 5 & 20 & \\
\hline A3 & 26 & 19 & \\
\hline A4 & 27 & 30 & \\
\hline B & 5 & 80 & ns \\
\hline
\end{tabular}

*Han sido excluidos 17 pacientes, 3 sin cirrosis y 14 con tumores incidentales en el explante.

nor $(\mathrm{p}<0,05)$ fueron la etiología distinta del alcoholismo, el tamaño y número de los nódulos tumorales, la invasión vascular macroscópica, un estadio T4 en la clasificación pTNM y la positividad para el VHC (Tabla III). La inva-
Tabla IV. Hepatocarcinoma en pacientes VHC positivos

\begin{tabular}{lll}
\hline & VHC positivo & VHC negativo \\
\hline Número de casos & 40 & 40 \\
Mortalidad (\%) & 37,5 & 17,5 \\
Recidiva tumoral (\%) & 25 & 12,5 \\
$\begin{array}{l}\text { Causa de la muerte (\%) } \\
\quad\end{array}$ & \\
$\quad$ Recidiva tumoral & $8(53,3 \%)$ & $4(57,1 \%)$ \\
$\quad$ Recidiva viral & $3(20 \%)$ & $1(14,3 \%)$ \\
$\quad$ Otros & $2(16,7 \%)$ & $4(28,1 \%)$ \\
Estadiaje tumoral (\%) & & \\
$\quad$ pT1 & 7,5 & 12,8 \\
pT2 & 30 & 35,9 \\
pT3 & 12,5 & 17,9 \\
pT4 & 50 & $33,3(\mathrm{p}=0,087)$ \\
\hline
\end{tabular}

sión vascular microscópica, aunque sin significación estadística $(\mathrm{p}=0,0807)$, también parece asociarse a una menor supervivencia. En el análisis multivariante únicamente la invasión vascular macroscópica se mostró como factor independiente asociado a una mayor mortalidad, con un riesgo relativo de 23.351, siendo su IC al $95 \%$ $(3.503,155.673)$.

\section{DISCUSIÓN}

En los últimos años han proliferado los intentos de establecer con claridad los factores que con mayor fiabilidad nos permitirían predecir el riesgo de recidiva del hepatocarcinoma tras el trasplante hepático $(8,9)$. A medida que el número de pacientes candidatos a esta intervención crece y, por el contrario, la disponibilidad de órganos es más escasa, la rigurosa selección de los pacientes cobra mayor importancia si cabe. La tendencia reciente ha sido la de indicar el trasplante a los pacientes con un nódulo tumoral único no superior a los $5 \mathrm{~cm}$ de diámetro y a los pacientes con un máximo de tres nódulos, siempre que el de mayor tamaño no excediese los $3 \mathrm{~cm}$. Estos criterios restrictivos (denominados criterios de Milán) han demostrado ser muy útiles a la hora de identificar a un grupo de pacientes con escasa posibilidad de recurrencia (5). Sin embargo, otros autores han demostrado igualmente unos excelentes resultados pese a ampliar de forma contenida la selección de los candidatos, por ejemplo hasta $6,5 \mathrm{~cm}$ en el caso de un tumor único o hasta $4,5 \mathrm{~cm}$ en caso de existir tres nódulos tumorales, sin exceder de $8 \mathrm{~cm}$ la suma total del diámetro tumoral (criterios de San Francisco) (10). En nuestro país, con unos criterios similares, Herrero y cols. demostraron una supervivencia libre de enfermedad del $70 \%$ a los 5 años del trasplante (11). Por tanto, la controversia se suscita por la exclusión, al aplicar criterios muy restrictivos, de un subgrupo de pacientes con escasa posibilidad de recurrencia tumoral (12).

Existe un consenso generalizado de que la clasificación TNM clásica carece de utilidad, dado que no predice de forma adecuada el riesgo de recidiva ni la supervivencia de los 
pacientes trasplantados. Además, si se compara la estadificación preoperatoria y postoperatoria (pTNM), la correlación en la mayoría de los casos es bastante pobre $(11,13-$ 15). En nuestra serie, los pacientes con un pT1, pT2 y pT3 no presentaban diferencias significativas en cuanto al riesgo de recidiva y la supervivencia media. Tan sólo el pT4 presentaba un riesgo significativamente mayor de recidiva tumoral y de mortalidad. No obstante, en este estadio se incluyen pacientes con un pronóstico bien diferente, si tenemos en cuenta los conocimientos actuales: parece lógico que un paciente con un nódulo único de $4 \mathrm{~cm}$, con invasión vascular macroscópica tenga peor pronóstico que un paciente con dos nódulos de dos centímetros, uno de ellos en LHD y otro en LHI, ambos sin invasión vascular.

Es la invasión vascular macroscópica el factor al que se le concede un mayor valor pronóstico en la mayoría de los trabajos, tanto en la predicción de la recidiva como en la supervivencia $(16,17)$. Nuestros resultados son concordantes con los resultados publicados hasta el momento. La gran limitación es que este hallazgo lo obtiene habitualmente el patólogo tras el examen del explante, cuando objetiva un vaso macroscópicamente visible (generalmente mayor de $2 \mathrm{~mm}$ ) infiltrado por el tumor. El objetivo claro sería, indudablemente, poder detectarla preoperatoriamente de forma fidedigna.

En contra de otras opiniones, no encontramos relación entre el nivel de alfafetoproteína y la posibilidad de recurrencia tumoral $(10,18)$. No encontramos diferencias significativas en lo referente al riesgo de recidiva ni influencia en la supervivencia. Cierto es que aquellos que le concedieron este valor, sólo obtuvieron significación estadística para un nivel superior a los 300 o incluso 1.000 $\mathrm{ng} / \mathrm{mL}$, mientras que en nuestro estudio el punto de corte se estableció en los $100 \mathrm{ng} / \mathrm{mL}$. En nuestra serie sólo había 8 pacientes con AFP > $300 \mathrm{ng} / \mathrm{ml}$.

En nuestro estudio, el tamaño de los nódulos mayor de $5 \mathrm{~cm}$ también se acompañó de un riesgo significativamente mayor de recidiva, aunque este hecho no se traduce en diferencias significativas en la supervivencia. Este dato también fue observado por otros autores $(19,20)$, quienes también encontraron diferencias significativas en cuanto a supervivencia y riesgo de recidiva en relación con el número de nódulos y su distribución uni o bilobular. En nuestro caso, estos factores alcanzaron significación estadística en el análisis univariante, pero no pudieron ser considerados factores de riesgo independientes tras el análisis multivariante.

Un hallazgo no compartido por otras series es la mortalidad significativamente mayor del grupo de pacientes con positividad para el VHC. Tras el estudio pormenorizado de estos enfermos (Tabla IV) observamos que, al igual que el resto de los pacientes con hepatocarcinoma trasplantados, fallecían en su mayoría como consecuencia de la recidiva tumoral. Aunque las diferencias no fueron estadísticamente significativas, pudimos comprobar que los pacientes HCV positivos se diagnostican en un estadio más avanzado, a pesar de que el seguimiento fue el mismo que en los otros grupos, y en todos ellos ajustado al consenso actual $(21,22)$. Se observa cómo al menos la mitad de los pacientes VHC positivos se diagnostican en estadio pT4, mientras que el 48,7\% de los VHC negativos se diagnosticaron en estadio pT1 o pT2 $(\mathrm{p}=0,087)$.

A la vista de los resultados que hemos obtenido, variables como el grado de diferenciación tumoral o que el hepatocarcinoma sea un hallazgo incidental en el explante, y no la indicación del trasplante, no tienen valor pronóstico. Es posible que el escaso número de pacientes con tumores mal diferenciados (el 15\%) impida alcanzar la significación estadística, que sí se ha demostrado en series amplias incluyendo los casi 800 trasplantes con hepatocarcinoma integrados en el Registro Internacional de Tumores (2326). Por otro lado, el escaso valor de los tumores incidentales ha sido recogido por otros autores (27), al demostrar hasta un 30\% de invasión vascular en ellos. Una forma de crecimiento expansivo y la ausencia de cápsula tumoral, aunque sin alcanzar significación estadística, se acompañan de un mayor riesgo de recidiva tumoral. Quizás esto esté en relación con que de esta manera es más factible un mayor crecimiento del tumor y la invasión vascular.

A modo de resumen podemos concluir que el estadiaje clásico TNM, además de anacrónico, es poco útil, que la invasión vascular macroscópica y el tamaño de los nódulos mayor de 5 centímetros permite predecir con bastante fiabilidad un mayor riesgo de recidiva, aunque sólo la invasión vascular macroscópica acorta significativamente la supervivencia y, finalmente, que los pacientes con hepatopatía crónica por HCV y hepatocarcinoma trasplantados tienen una menor supervivencia a largo plazo, probablemente porque el tumor está en un estadio más avanzado en el momento del diagnóstico. 